\title{
Potential Feedstock Sources for Ethanol Production in Florida 1
}

Mohammad Rahmani and Alan Hodges ${ }^{2}$

\section{Introduction}

The United States is dependent upon imported petroleum for over 60 percent of its transportation fuels. Bio-fuels such as ethanol and bio-diesel have significant potential to substitute for petroleum to reduce this dependence on imported fossil fuels. The oxygen content in bio-fuels also provides important environmental benefits for reducing pollutant emissions (SOx, NOx), and reducing net additions to atmospheric $\mathrm{CO}_{2}$; thereby mitigating potential harmful effects of global climate change. Presently, production of ethanol in the United States is about 4 billion gallons annually, and is an important component of the motor fuel supply. The corn-ethanol industry's annual operations and capital spending for new plants under construction added a total of $\$ 32.2$ billion of gross output to the U.S. economy in 2005. As a consequence of increased economic activity caused by ethanol production activities, more than 153,000 jobs have been added in all sectors of the U.S. economy, including over 19,000 jobs in America's manufacturing sector. The production of ethanol will put an additional $\$ 5.7$ billion into the pockets of U.S. consumers, and will add more than $\$ 1.9$ billion of tax revenue for the federal government and nearly $\$ 1.6$ billion for state and local governments in 2006 (Urbanchuk, 2006). It should be noted that government subsidies of about $\$ 1.4$ billion to fuel blenders (a tax credit of 51 cents per gallon of fuel ethanol) plus $\$ 4$ billion to corn producers have encouraged the corn-to-ethanol program in the United States (Pimentel, 2003; The New Atlantis, 2006).

Ethanol is mixed with gasoline at rates of 5 to 85 percent to make reformulated gasoline. Most fuel-grade ethanol in the United States is currently produced from corn, an abundant, low-cost commodity, concentrated in the U.S. mid-western region. Presently, there are two types of ethanol-blended automobile gasolines: E10 and E85. E10, which is the most common type of ethanol-blended gasoline, containing 10 percent ethanol and 90 percent unleaded gasoline, can be used in most cars, and can be purchased at many gas stations. E85 is a blend that contains 85 percent ethanol and 15 percent gasoline, but can be used only in Flexible Fuel Vehicles (FFVs), and can be found only in a few gas stations in the United States (Pollack, 2005). Currently, there are about 600 E85 fuel stations (compared to about 170,000 gasoline

1. This is EDIS document FE650, a publication of the Food and Resource Economics Department, Florida Cooperative Extension Service, Institute of Food and Agricultural Sciences, University of Florida, Gainesville, FL. Published July 2006. Please visit the EDIS website at http://edis.ifas.ufl.edu.

2. Mohammad Rahmani, Coordinator of Economic Analysis, and Alan Hodges, Associate In, Food and Resource Economics Department, Florida Cooperative Extension Service, Institute of Food and Agricultural Sciences, University of Florida, Gainesville, FL.

The Institute of Food and Agricultural Sciences (IFAS) is an Equal Opportunity Institution authorized to provide research, educational information and other services only to individuals and institutions that function with non-discrimination with respect to race, creed, color, religion, age, disability, sex, sexual orientation, marital status, national origin, political opinions or affiliations. U.S. Department of Agriculture, Cooperative Extension Service, University of Florida, IFAS, Florida A. \& M. University Cooperative Extension Program, and Boards of County Commissioners Cooperating. Larry Arrington, Dean 
stations), and 5 million FFVs (mostly as fleet vehicles) in the United States (Mello, 2006)

To take advantage of the favorable climatic conditions for biomass and bio-fuel production, Florida has over 20 years of experience in research and development on various aspects of biomass crop production and conversion of biomass to energy sources such as ethanol, methane, and electricity. Research and extension centers of the University of Florida's Institute of Food and Agricultural Sciences, located throughout Florida, are involved in conducting research on various aspects of biomass production and utilization (Rahmani et al., 2000). For example, the Citrus Research and Education Center in Lake Alfred has conducted studies on conversion of citrus byproducts to ethanol.

This paper presents information on the potential feedstock sources that may be used for ethanol production in Florida. Conversion of cellulosic materials to ethanol has not been considered as a near-term technology in this publication. While cellolosic materials such as wood and grasses may be converted to ethanol, the saccharification of cellulose is difficult and complex, requiring micro-organism development in laboratories via genetic engineering (Ingram and Doran, 1995). This conversion methodology has yet to be applied on a commercial scale.

\section{Potential Feedstocks for Fuel Ethanol Production in Florida}

\section{Sugarcane}

Sugarcane is one of Florida's major crops that can be grown throughout the state; however, it is grown commercially only in the southern part of the state for production of crystallized sugar, where soil and climatic conditions are most favorable.

Sugarcane grown on about 400,000 acres in Florida produced 13.4 million tons in the 2004-05 season and 17.3 million tons in the 2001-02 season (Baucum et al., 2006). Average sugarcane yields range from 32 to 38 tons per acre, and vary based on characteristics of soil type, crop year, harvesting, and other agricultural practices. While sugarcane is not a new crop in Florida, growing it as feedstock for ethanol may be considered a new use. It should be noted that at the present time, there is no facility for conversion of sugarcane to ethanol in Florida; however, there is the potential for sugarcane-to-fuel ethanol production.

The average cost of sugarcane and its sugar content are important factors for producing ethanol from sugarcane. These factors depend on the variety of sugarcane, type of soil, field preparation, and other agricultural practices, and may also vary by crop year. Estimates of average sugarcane cost range from $\$ 30$ to $\$ 35$ per ton, including harvesting. Sugarcane contains about 85 percent juice, which has roughly 11 percent sugar by weight (Baucum et al., 2006).

There are two main components to the conversion of ethanol from sugarcane: (1) production of sugarcane and pressing to obtain sugarcane juice, and (2) fermentation of juice to ethanol and dehydration. Since the cost of producing sugarcane is dependent on several factors, the cost of ethanol from sugarcane in Florida can be estimated within a range. Presently, there is no commercial sugarcane used for fuel ethanol in Florida; therefore the data for estimating the processing costs is based on Brazilian data adjusted for higher labor costs in Florida. The cost of sugarcane delivered at the mill represents nearly two-thirds of the final ethanol cost (Leitz, 2005). A more detailed cost estimate puts the cost of ethanol processing in Brazil at $\$ 0.32$ a gallon (Coelho, 2005). Considering all aspects, the processing cost of sugarcane juice to ethanol in Florida was estimated at $\$ 0.50$ per gallon (Coelho, 2005; Regis Lima Verde Leal, 2005). This figure also includes the benefit of burning bagasse (sugarcane byproduct) which reduces the cost of processing. Cost estimates were based on 200 gallons of sugarcane juice from 1 ton of sugarcane. Conversion rates for sugarcane juice to ethanol may vary based on sugar content. Higher sugar content produces more ethanol. As can be seen in Table 1, the cost of ethanol production from sugarcane in Florida was estimated for four scenarios representing various production costs and sugar content. The total cost varies from a low of $\$ 2.00$ to a high of $\$ 2.56$ per gallon of ethanol, based on the effect of these factors.

Within the past 25 years, sugarcane yield has improved by 33 percent, sugar content increased by 8.5 percent, extraction efficiency increased from 90 
to 97.5 percent, fermentation efficiency increased from 82 to 91 percent, and the fermentation period has been reduced from 16 hours to less than 9 hours (Coelho, 2005). It should be noted, however, that a sugarcane price of $\$ 11.4$ per ton, feedstock cost of $\$ 0.54$ per gallon of ethanol, and total cost of produced ethanol of $\$ 0.87$ per gallon in Brazil have not been achieved as a result of technological advancement alone but by the favorable climatic conditions and lower labor costs in that country (Coelho, 2005). In addition, while the average yield of sugarcane per acre in Brazil and the United States is similar, sugarcane in Brazil is not irrigated (Walter et al., 2006).

\section{Corn}

As the predominant source for the production of about 4 billion gallons of ethanol in the United States, corn could also be considered a potential source of ethanol production in Florida. North Florida, particularly the area adjacent to the Suwannee River, has the potential for growing corn as a feedstock for conversion to ethanol. Results from corn variety studies in North Florida have shown corn yields of over 170 bushels per acre for short-season, irrigated varieties, and 160 bushels per acre for full- and mid-season irrigated varieties (Wright et al., 2004). However, the cost of producing high-yield corn on irrigated land in Florida is almost twice that for the major U.S. corn-producing states (Hewitt, 2006a). Another problem is the contamination of Florida corn with aflotoxin (a fungous disease), which makes the corn byproduct (Distillers Dried Grains, or DDG) unsuitable for animal feeding. This could increase the cost of ethanol from corn in Florida; but this problem could be mitigated by using resistant corn varieties.

Production of ethanol from corn in the United States is an established technology. One bushel of corn can be converted to 2.7 gallons of ethanol (Baker and Zahniser, 2006). Ethanol produced from corn costs about $\$ 1.20$ per gallon (Shapouri et al., 2002; Wagner, 2006). These numbers are for corn grown in the major U.S. corn-producing states. In Florida, there has been no corn-to-ethanol production effort because the cost of producing corn in Florida (\$3.15-\$5.50 per bushel for irrigated corn, and \$3.94-\$6.89 per bushel for dry-land corn) is much higher than the national average of \$1.95-\$2.05 per bushel (Hewitt, 2006a; Baker and Allen, 2006). In addition, the issue of the suitability of DDG for animal feeding may make the cost of ethanol from Florida-grown corn even higher. Assuming a favorable scenario of an average yield of 150 bushels of irrigated corn per acre, the cost of grain corn would be $\$ 3.67$ per bushel (Hewitt, 2006a). With suitable DDG for animal feeding, the cost of ethanol from Florida-grown corn would be about $\$ 1.82$ a gallon.

There is currently a plan by some investors to buy corn from the U.S. mid-western states as feedstock for corn-to-ethanol production in Florida (Keller, 2006). It will take time to find out how economically feasible this commercial endeavor will be. Apparently, the feasibility study results have been positive. A state construction permit for an $\$ 80$ million ethanol production plant with a 40-million gallon capacity at the Port of Tampa in Florida has been granted (Keller, 2006). Based on a corn price of \$1.95-\$2.05 per bushel for the 2005-06 crop year (Baker and Allen, 2006), the cost of ethanol from corn is estimated at $\$ 1.20$ a gallon. This cost includes the value of DDG as a credit. About 6.4 pounds of DDG is produced for each gallon of fuel ethanol. At a sale price of $\$ 0.045$ per pound, DDG reduces the total price of produced ethanol by $\$ 0.28$ per gallon (McAoon et al., 2000). A \$1 increase in the corn price would increase the price of ethanol by about $\$ 0.37$ per gallon (at 2.7 gallons of ethanol per bushel of corn). The conversion of corn shipped to Florida from other states can also be taken into consideration, assuming that the transportation cost would be less than $\$ 1$ per bushel. A barge transportation rate could not be found for shipments from the corn-producing states to the Port of Tampa; however, a comparison of corn transportation rates to other ports indicates that the transportation rate should be below $\$ 1$ per bushel (Hart and Yu, 2005).

The capital cost of a corn-to-ethanol plant is based on capacity, type of equipment, wastewater treatment, processing $\mathrm{CO}_{2}$, and grain-ethanol milling (wet milling, dry milling). The optimum capacity depends on several factors, with feedstock availability being the major factor. Based on various factors, a grain-ethanol dry-mill facility of 40 to 65 million 
gallons per year is considered the optimum capacity. Higher capacity requires abundant feedstock available nearby. The average capital cost for an optimum capacity dry-mill grain-ethanol is estimated at about $\$ 2$ per gallon of output (BBI International, 2001). Therefore, an ethanol plant with a 40-million gallon capacity would require approximately $\$ 80$ million in capital expenditures.

\section{Citrus Byproducts}

Citrus molasses is a byproduct of citrus-juice processing that can be readily converted to ethanol. The availability of citrus industry byproducts (e.g., citrus molasses) that could be converted to fuel ethanol provides another ethanol source in Florida. Citrus byproducts have been used mainly for animal feeding purposes. There are some facilities in Florida that process citrus molasses to produce beverage ethanol; however, there has not been any experience with conversion of citrus byproducts to fuel ethanol.

More than 38,000 tons of citrus molasses were produced in the 2003-04 production year (Florida Citrus Processors Association). Presently, 72-degree Brix citrus molasses is used to produce beverage ethanol and for the formulation of sweetened cattle feed. "Citrus molasses has been used as a substrate for the bioconversion of peel sugars to ethanol for 50 years. This ethanol is produced in a traditional batch yeast fermentation from the molasses and is primarily used as a neutral spirits for manufacture of alcoholic beverages" (Braddock, 1999). The price of citrus molasses depends on several factors of which total citrus crop yield in a year is considered to have a major effect. Delivered prices, including transportation cost to conversion facilities, have ranged from $\$ 80$ to $\$ 100$ per ton during the last few years. Long-run (15 years) projections for Florida citrus production indicate a slight yearly decrease, which is going to affect the production of citrus byproducts as well (Spreen et al., 2006).

The Florida citrus industry produces an average of 40,000 tons of citrus molasses per year (Florida Citrus Processors Association). This amount may vary by several thousand tons based on total citrus production volume per crop year. Some citrus byproducts (e.g., citrus peel) have more sugar content than citrus molasses, but citrus molasses is technically easier to convert to ethanol (Braddock, 1999). This is a practice that has been used by distiller facilities for many years. Based on the technical data (Braddock, 1999), 1 ton of molasses is about 184 gallons and, on average, 4 gallons of molasses is used to produce 1 gallon of ethanol. One ton of citrus molasses can be converted to about 46 gallons of ethanol (96\% alcohol), and 40,000 tons of molasses can produce 1.84 million gallons of ethanol. With the cost of 1 ton of citrus molasses delivered at conversion facilities at between $\$ 80$ and $\$ 100$, the feedstock cost of 1 gallon of ethanol (96\% alcohol) would range from $\$ 1.74$ to $\$ 2.17$. Adding to this the average processing cost of $\$ 0.50$, the total cost of 1 gallon of ethanol from citrus molasses would be between $\$ 2.24$ and \$2.67. This ethanol is not fuel grade, and it has to be dehydrated to get 99.9 percent alcohol, which increases the total cost. Ethanol loses about 4 percent of its volume when it is dehydrated (Regis Lima Verde Leal, 2005), and the cost of dehydration, including the volume loss, raises the cost of fuel ethanol from citrus molasses by $\$ 0.06$ to $\$ 0.10$ per gallon (Lilliston, 2005). Adding the dehydration cost, fuel ethanol from citrus molasses would cost between $\$ 2.30$ and $\$ 2.77$ per gallon.

\section{Sweet Sorghum}

Sweet sorghum is another possible source for ethanol, but there has been no experience on a commercial scale. In Florida, sorghum is grown for grain and silage (National Agricultural Statistics Service, 2004).

The silage type of sweet sorghum is the type suitable for ethanol production. In Florida, there are over 3,500 acres of sweet sorghum for silage, with a total yield of over 35,000 tons (National Agricultural Statistics Service, 2004). A 1995 demonstration project funded by the National Renewable Energy Laboratory, Department of Energy, looked into the possibility of using sweet sorghum (among other crops) for conversion to ethanol in Central Florida. The results did not provide any clear indication of feasibility for growing sorghum for ethanol using conventional technology. Since the study was done on reclaimed lands in central Florida, some technical issues, such as harvesting on particular soil types, appeared to hinder the agricultural practices during 
the rainy season. Both sweet and forage sorghum have a high risk for lodging that can result in harvest problems, with ensuing loss of yield from both the initial and ratoon crops (Stricker, 1996).

Sweet sorghum can produce up to 10 dry tons per acre. The cost of sorghum production and its sugar content are crucial for conversion of sorghum to ethanol. In Florida, sweet sorghum (USDA M81E) on clay tailings from phosphate mining has yielded about 13 dry tons per acre (Stricker, 1996). Costs of producing (growing and harvesting) sorghum for silage vary based on the cultivar, soil conditions, harvesting, and agricultural practices. In the North Florida region, silage sorghum yield ranges from 3.5 to 6.3 dry tons per acre, and production costs, including harvesting, ranges from $\$ 50$ to $\$ 90$ per dry ton (Hewitt, 2006b).

Based on results of a study on growing and converting sorghum to ethanol (McBee et al., 1988), 1 acre of sorghum can yield up to 7.59 tons of oven-dried stem and about 1,240 pounds of grain. One acre of sorghum (Rio cultivar) can produce 364 gallons of ethanol, whereas the next best cultivar (M35-1) produced about 166 gallons of ethanol per acre. Other cultivars registered lower yields for stem but higher grain per acre. Based on this data, 1 ton of sorghum can yield 22 to 48 gallons of ethanol. While there are some cost estimates for sorghum production in Florida, there is no cost estimate for conversion of sorghum to ethanol. Costs associated with conversion include transportation to processing facilities, juice extraction, and processing to ethanol. Without a sorghum-to-ethanol conversion facility to obtain reliable data, any estimates may be speculative. However, based on data from other types of sugar containing juice processing, estimates of about $\$ 0.75$ per gallon of ethanol can be made for all the associated conversion costs. With an estimated cost of sorghum as feedstock of $\$ 64$ per ton (median cost), the estimated cost of ethanol from sorghum ranges from $\$ 2.08$ to $\$ 3.65$ per gallon (Table 2). The sorghum-to-ethanol study did not indicate the alcohol content of the ethanol produced.

\section{Conclusions}

The best potential scenario for ethanol production in Florida showed the cost of ethanol from corn and sugarcane at $\$ 1.82$ and $\$ 2.00$ per gallon, respectively. The lowest cost ethanol from citrus molasses and sorghum was estimated at \$2.34 and $\$ 2.18$ per gallon, respectively. Ethanol cost estimates for molasses and sorghum included a dehydration cost of $\$ 0.10$ per gallon. The economic feasibility of each of these crops requires further data and technical analysis. So far, only corn shipped from other states to Florida has been considered for ethanol production on a commercial scale.

Sugarcane is an established crop in Florida. Processing sugarcane juice to ethanol is an established technology in Brazil, which has proven to be very successful. Productivity in sugarcane production and efficiency in juice processing and ethanol production have been improved drastically. Any effort toward implementing a sugarcane-to-ethanol industry in Florida has to consider issues such as waste management, sugarcane production costs, and the impact on the sugar market. Currently, the U.S. sugar policy has two main elements: the non-recourse loan program, which supports the U.S. price of sugar, and the tariff-rate quota import system (TRQ), which ensures that there is an adequate supply of sugar at reasonable prices for both consumers and producers (Haley, 2005). As the sole feedstock source for sugar production in Florida, alternative uses of sugarcane may affect the quantity of sugar production in Florida, which eventually may have some impact on U.S. sugar policy. While analyzing this impact is beyond the scope of this paper, the extent of such probable impacts may be analyzed once the alternative uses of sugarcane are taken into consideration.

While citrus molasses is converted to ethanol as an established process, the cost of ethanol is higher, and the total amount of citrus molasses per year is insignificant. Even if the total yearly production of about 40,000 tons were processed to ethanol, the total ethanol produced would be about 1.84 million gallons, which is less than half of a percent of total ethanol production from corn in the United States. Ethanol processing is sub-economic for plants typically less than 40 million gallons per year. 
Sorghum cultivars have the potential for ethanol production; however, the agricultural practices for growing sweet sorghum for ethanol have not been established, and the conversion process must be tested and developed at a more expanded level. Considering all aspects, it seems that with the present price of about $\$ 3$ per gallon for ethanol, it may still be economically viable to ship corn from major corn-producing states to produce ethanol in Florida. Also, if corn can be produced at about $\$ 3$ a bushel in Florida and its DDG suitability for animal consumption is assured, it may still be a viable option to grow corn and convert it to ethanol. Considering the best possible scenarios, Table 3 compares the cost per gallon and yield per acre for ethanol from selected feedstocks in Florida.

\section{References}

BBI International. 2001. Ethanol Plant

Development Handbook, Third Edition. Salida, CO: BBI International.

Baker, A., and E. Allen. 2006. Feed Outlook. Electronic Outlook Report FDS-06d. Economic Research Service, United States Department of Agriculture, Washington, D.C. ,(May 16). http://usda.mannlib.cornell.edu/reports/erssor/field/ fds-bb/2006/fds06d.pdf.

Baker, A., and S. Zahniser. 2006. Ethanol Reshapes the Corn Market. Economic Research Service, United States Department of Agriculture, Washington, D.C. (April). http://www.ers.usda.gov/AmberWaves/April06/ Features/Ethanol.htm.

Baucum, L.E., R.W. Rice, and T.G. Schuneman. 2006. An Overview of Florida Sugarcane. Electronic Data Information Source (EDIS) SC032. Agronomy Department, University of Florida, Gainesville, FL. http://edis.ifas.ufl.edu/SC032.

Braddock, Robert J. 1999. Handbook of Citrus By-Products and Processing Technology. New York, NY: John Wiley \& Sons, Inc.
Coelho, Suani. 2005. Brazilian Sugarcane Ethanol: Lessons Learned. The Brazilian Reference Center on Biomass. STAP Workshop on Liquid Biofuel, New Delhi, India (August 29-September 1). http://stapgef.unep.org/docs/folder.2005-1207.8158774253/folder.2005-12-08.9446059805/ folder.2005-12-08.0238464777/folder.2005-1220.8533782016/

Brazilian\%20Sugarcane \%20Ethanol\%20$\% 20$ Lessons\%20Learned, $\% 20$ Prof\%20Suani\%20Coelho.pdf.

Florida Citrus Processors Association. Statistical Summary 2003-04 Season. FCPA, Winter Haven, FL. http://www.fcplanet.org/arch_weekly/ FCPA\%20YrBk\%200304.pdf.

Haley, S. 2005. Sugar and Sweeteners: Policy. Briefing Rooms, Update. Economic Research Service, United States Department of Agriculture, Washington, D.C. (June 1). http://www.ers.usda.gov/Briefing/Sugar/Policy.htm.

Hart, C.E., and Tun-Hsiang Yu. 2005. Agricultural Situation Spotlight: Corn Prices, Basis, and Transportation. Iowa Ag Review 11(4). http://www.card.iastate.edu/iowa_ag_review/fall_05/ article2.aspx.

Hewitt, T. 2006a. Two Reports - Estimated Costs of One Acre of Irrigated Corn, North Florida; and Estimated Costs of One Acre of Dryland Corn, North Florida. North Florida Research and Education Center, University of Florida, Marianna, FL. http://nfrec.ifas.ufl.edu/Hewitt/Budgets/ field\%20crop\%20irrig\%20corn.xls and http://nfrec.ifas.ufl.edu/Hewitt/Budgets/ field $\% 20$ crop $\% 20$ dryland $\% 20$ corn.xls.

Hewitt, T. 2006b. Estimated Costs of One Acre of Grain Sorghum, North Florida. North Florida Research and Education Center, University of Florida, Marianna, FL. http://nfrec.ifas.ufl.edu/Hewitt/Budgets/ field $\% 20$ crop $\% 20$ grain $\% 20$ sorghum.xls.

Ingram, L.O., and J.B. Doran. 1995. Conversion of Cellulosic Materials to Ethanol. FEMS Microbiology Reviews 16(2):235-241. 
Keller, A. 2006. Starter Fuel. Florida Trend Magazine (May).

Leitz, Rogerio Cezar de Carqueira. 2005. Overview of Biomass Energy Processes from Primary Sources to End Use, Liquid Fuel. $R \& D$ of Energy Technology, Annex AIII-Renewable Energy, 109-191. Interdisciplinary Center for Energy Planning, State University of Campinas, Sao Paulo, Brazil. http://www.iupap.org/wg/energy/annex-1c.pdf.

Lilliston, B. 2005. CAFTAs Impact on U.S. Ethanol Market. Institute for Agriculture and Trade Policy, Minneapolis, MN (June).

http://www.tradeobservatory.org/ library.cfm?refid=73232. [A \$10 million ethanol dehydration facility will have a capacity of about 63 million gallons annually].

McAoon, A., F. Taylor, W. Yee, K. Ibsen, and R. Wooley. 2000. Determining the Cost of Producing Ethanol from Corn Starch and Lignocellulosic Feedstocks. NREL/TO-580-28893. National Renewable Energy Laboratory, Golden, CO (October). http://webdev.its.iastate.edu/webnews/data/ site_biorenew_reading/14/webnewsfilefield_file/ Cost-of-Ethanol.pdf.

McBee, G.G., R.A. Creelman, and F.R. Miller. 1988. Ethanol Yield and Energy Potential of Stems from a Spectrum of Sorghum Biomass Types. Biomass 17(3):203-211.

Mello, T.B. 2006. Fueling Up with Ethanol: Are Flexible Fuel Vehicles the Answer to Our Oil Addiction? Edmunds Online (February 7). http://www.edmunds.com/advice/fueleconomy/ articles/109194/article.html.

National Agricultural Statistics Service. 2004. 2002 Census of Agriculture, Florida State and County Data, Volume 1, Geographic Area Series, Part 9, AC-02-A-9. NASS, United States Department of Agriculture, Washington, D.C. (June). http://www.nass.usda.gov/census/census02/volume1/ fl/fl1intro.pdf.

New Atlantis Editors. 2006. Addicted to Bad Data, Getting the Facts Straight on Ethanol. The New
Atlantis, A Journal of Technology \& Society, A Survey of Technology and Society 12:119-121. http://www.thenewatlantis.com/archive/12/soa/ ethanol.htm.

Pimentel, D. 2003. Ethanol Fuels: Energy Balance, Economics, and Environmental Impacts Are Negative. Natural Resources Research 12(2). http://www.ethanol-gec.org/netenergy/ neypimentel.pdf.

Pollok, J.E. 2005. Ethanol-America's Renewable Fuel. Check Off Report and Newsletter, Corn Marketing Program of Michigan, Dewitt, MI. http://www.micorn.org/downloads/ EthanolNewsltrAug05.pdf.

Rahmani, M., A.W. Hodges, C.F. Kiker, and A. Shiralipour. 2000. Biomass Research and Development in Florida: Results of Twenty Years Experience. Proceedings of Bioenergy 2000, The Ninth Biennial Bioenergy Conference, Buffalo, NY (October 15-19).

Regis Lima Verde Leal, M. 2005. Better Sugar; Better Business, Mill Issues and Co-Products. WWF Workshop, London, UK (June23-24).

http://assets.panda.org/downloads/ millissuesandcoproducts.pdf.

Shapouri, H., J.A. Duffield, and M. Wang. 2002. The Energy Balance of Corn Ethanol: An Update. Agricultural Economic Report Number 813. Office of Energy Policy and New Uses, United States Department of Agriculture, Washington, D.C. (July).

Spreen, T.H., R.E. Barber, Jr., M.G. Brown, A.W. Hodges, J.C. Malugen, W.D. Mulkey, R.P. Muraro, R.P. Norberg, M. Rahmani, F.M. Roka, and R.E. Rouse, 2006. An Economic Assessment of the Future Prospects for the Florida Citrus Industry. Florida Department of Citrus, Lakeland, FL and University of Florida, Gainesville, FL (March). http://www.fred.ifas.ufl.edu/ economic_assess_flciturus_indus.pdf.

Stricker, James A. (Editor). 1995. Economic Development through Biomass Systems Integration in Central Florida. Technical Report, National Renewable Energy Laboratory, Golden, CO (May15). 
Urbanchuk, J.M. 2006. Contribution of the

Ethanol Industry to the Economy of the United

States. Renewable Fuels Association, Washington.

D.C. (Feb. 21).

Wagner, K. 2006. Fuel from Corn. The Kansas

City Star, (May 17). Accessed online July 24, 2006 at

http://www.kansascity.com/mld/kansascity/

14596471.htm.

Walter, A., Paulo Dolzan, and Erik Piacente.

2006. Biomass Energy and Bio-energy Trade:

Historic Development in Brazil and Current

Opportunities. Country Report: Brazil - Task 40 -

Sustainable Bio-energy; Securing Suppy and

Demand, Final Version, State University of

Campinas - Unicamp, Campinas, Brazil.

http://www.bioenergytrade.org/plaintext/downloads/

brazilcountryreport.pdf.

Wright, D.L., J.J. Marois, P.J. Wiatrak, and B.

Kidd. 2004. Florida 2003 Short, Mid, and Full Season

Corn Variety Tests for Silage and Grain. Electronic

Data Information Source (EDIS) AG227. Agronomy

Department, University of Florida, Gainesville, FL.

http://edis.ifas.ufl.edu/AG227. 
Table 1. Estimated cost of ethanol from sugarcane in Florida.

\begin{tabular}{|c|c|c|c|}
\hline $\begin{array}{l}\text { Cost of Sugarcane } \\
\text { Production and } \\
\text { Harvesting }\end{array}$ & Ethanol Yield & Feedstock Cost & $\begin{array}{l}\text { Total Cost of Ethanol } \\
\text { from Sugarcane }\end{array}$ \\
\hline (dollars/ton) & (gallons/ton) & (dollars/gallon) & (dollars/gallon) \\
\hline$\$ 30$ & 20 & $\$ 1.50$ & $\$ 2.00$ \\
\hline$\$ 30$ & 17 & $\$ 1.77$ & $\$ 2.27$ \\
\hline$\$ 35$ & 20 & $\$ 1.75$ & $\$ 2.25$ \\
\hline$\$ 35$ & 17 & $\$ 2.06$ & $\$ 2.56$ \\
\hline
\end{tabular}

Table 2. Estimated cost of Ethanol from Various Sorghum Cultivars in Florida.

\begin{tabular}{|cccc|}
\hline \hline $\begin{array}{c}\text { Cost of Sorghum } \\
\text { Production }\end{array}$ & Ethanol Yield & Feedstock Cost & $\begin{array}{c}\text { Total Cost of Ethanol } \\
\text { from Sorghum }\end{array}$ \\
\hline (dollars/ton) & (gallons/ton) & (dollars/gallon) & (dollars/gallon) \\
$\$ 64$ & 48 & $\$ 1.33$ & $\$ 2.08$ \\
$\$ 64$ & 22 & $\$ 2.90$ & $\$ 3.65$ \\
\hline \hline
\end{tabular}

Table 3. Ethanol cost and yield for selected feedstocks in Florida (best potential scenario).

\begin{tabular}{|cccccc|}
\hline \hline & & Corn $^{*}$ & Sugarcane & Sweet Sorghum & Citrus Molasses \\
\hline Cost & (dollar/gallon) & $\$ 1.82$ & $\$ 2.00$ & $\$ 2.18$ & $\$ 2.34$ \\
Yield & (gallon/acre) & 405 & 595 & 302 & $\mathrm{~N} / \mathrm{A}$ \\
\hline $\begin{array}{l}\text { * Based on } \$ 3.67 \text { per bushel cost of corn. } \\
\mathrm{N} / \mathrm{A}=\text { Not Applicable }\end{array}$ & & & & \\
\hline \hline
\end{tabular}

